\title{
Healthy aging promotion model referenced in Nola Pender's theory
}

\author{
Modelo de promoção de envelhecimento saudável referenciado na teoria de Nola Pender \\ Modelo de promoción de envejecimiento saludable referido en la teoría Nola Pender
}

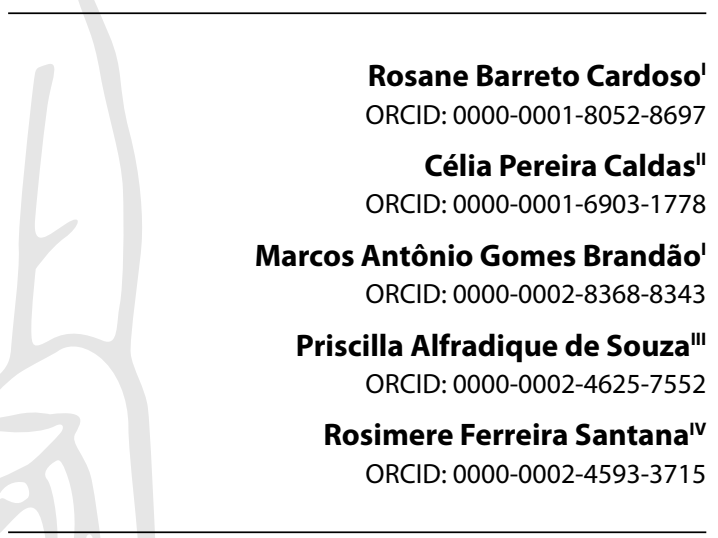

'Universidade Federal do Rio de Janeiro. Rio de Janeiro, Rio de Janeiro, Brazil.

"Universidade do Estado do Rio de Janeiro. Rio de Janeiro, Rio de Janeiro, Brazil.

I'Universidade Federal do Estado do Rio de Janeiro. Rio de Janeiro, Rio de Janeiro, Brazil.

"Universidade Federal Fluminense. Niterói, Rio de Janeiro, Brazil.

How to cite this article: Cardoso RB, Caldas CP, Brandão MAG, Souza PA, Santana RF. Healthy aging promotion model referenced in Nola Pender's theory. Rev Bras Enferm. 2022;75(1):e20200373. https://doi.org/10.1590/0034-7167-2020-0373

Corresponding author:

Rosane Barreto Cardoso

E-mail: rosane.bcardoso@gmail.com

EDITOR IN CHIEF: Dulce Barbosa ASSOCIATE EDITOR: Rafael Silva

\begin{abstract}
Objectives: to model the process of promoting healthy aging from the conceptual analysis proposed by Walker and Avant and Nola Pender's Health Promotion Model. Methods: this is a descriptive and theoretical study, with a qualitative approach. Elements resulting from conceptual analysis were used to model a healthy aging promotion process based on Nola Pender's Health Promotion Model. Results: in conceptual analysis, seven antecedents, seven attributes and three consequences of the concept of healthy aging were identified. Final Considerations: the proposed Health Promotion Model represents a structure that in an instrumental way can guide the nursing process application in gerontological clinical practice. This can guide nurses in identifying diagnoses, establishing outcomes and implementing interventions aimed at promoting the elderly's health.

Descriptors: Health Promotion; Nursing Theory; Healthy Aging; Nursing Process; Health of the Elderly.
\end{abstract}

\section{RESUMO}

Objetivos: modelar o processo de promoção de envelhecimento saudável a partir da análise conceitual proposta por Walker e Avant e do referenciamento do Modelo de Promoção da Saúde de Nola Pender. Métodos: estudo descritivo e teórico, com abordagem qualitativa. Utilizaram-se elementos resultantes da análise conceitual para modelar um processo de promoção de envelhecimento saudável a partir do Modelo de Promoção da Saúde de Nola Pender. Resultados: na análise conceitual, foram identificados sete antecedentes, sete atributos e três consequências do conceito de envelhecimento saudável. Considerações Finais: o Modelo de Promoção da Saúde proposto representa uma estrutura que, de forma instrumental, pode orientar a aplicação do processo de enfermagem na prática clínica gerontológica. Este poderá direcionar o enfermeiro na identificação de diagnósticos, estabelecimento de resultados e implementação de intervenções voltadas à promoção da saúde do idoso.

Descritores: Promoção da Saúde; Teoria de Enfermagem; Envelhecimento Saudável; Processo de Enfermagem; Saúde do Idoso.

\section{RESUMEN}

Objetivos: modelar el proceso de promoción del envejecimiento saludable a partir del análisis conceptual propuesto por Walker y Avant y la referenciación del Modelo de Promoción de la Salud por Nola Pender. Métodos: estudio descriptivo y teórico, con enfoque cualitativo. Los elementos resultantes del análisis conceptual se utilizaron para modelar un proceso de promoción del envejecimiento saludable a partir del Modelo de Promoción de la Salud de Nola Pender. Resultados: en el análisis conceptual se identificaron siete antecedentes, siete atributos y tres consecuencias del concepto de envejecimiento saludable. Consideraciones Finales: el Modelo de Promoción de la Salud propuesto representa una estructura que, de manera instrumental, puede orientar la aplicación del proceso de enfermería en la práctica clínica gerontológica. Esto puede orientar al enfermero en la identificación de diagnósticos, el establecimiento de resultados y la implementación de intervenciones dirigidas a promover la salud de los ancianos. Descriptores: Promoción de la Salud; Teoría de Enfermería; Envejecimiento Saludable; Proceso de Enfermería; Salud del Anciano. 


\section{INTRODUCTION}

Population aging draws attention due to its heterogeneity and multidimensionality, being influenced by socio-cultural, political, economic, epidemiological and subjective aspects ${ }^{(1)}$. Therefore, the growth of the elderly population has substantial implications for nursing care in the need to offer specific care required by the chronicity, complexity and particularity of this age group, implying increasing demands on the health system and society ${ }^{(1-3)}$.

Aging represents a process to be lived in a healthy way and that demands health promotion actions for aging with quality of life ${ }^{(1-3)}$. Health promotion has stood out worldwide as an important tool in the search for the construction of the expanded concept of health that prioritizes actions to improve the population's quality of life $\mathrm{e}^{(3-4)}$. Among the elderly's demands for the health system, actions to promote healthy aging stand out, which are still incipient.

Studies ${ }^{(3-5)}$ point out the relevance of nursing actions in reaching health promotion. Such actions, besides providing the maintenance of functional capacity, should contribute to the construction of elderly's independence, autonomy, self-care and self-esteem, and consequently quality of life. However, in order to promote health, it is necessary for nurses to understand the aging process, differentiating the physiological and pathological changes inherent to the stage of life, in order to implement appropriate interventions $^{(2-3)}$. However, the proposals of nurses in actions aimed at promoting healthy aging are still timid, as the main focus has still been on the prevention and cure of diseases.

Requirements geared towards promoting healthy aging have encouraged regional and global initiatives. Since the 1990s, the World Health Organization (WHO) has been launching challenges to promote the health and quality of life of the aging population, aiming not only at increasing life expectancy ${ }^{(1)}$. Healthy aging promotion was the central focus of the WHO global report on aging and health ${ }^{(1)}$, published in 2015:

This report describes a public health framework for action that is built on the concept of Healthy Aging. This social response to an aging population will require a transformation of health systems away from curative models based on disease and towards the provision of comprehensive care focused on older adults. It will require the development, sometimes from scratch, of comprehensive long-term care systems. It will also require a coordinated response from other diverse sectors and multiple levels of government. It must be built on a fundamental shift in our understanding of aging to one that takes into account the diversity of larger populations and responds to the inequalities that often underlie ${ }^{(1)}$.

However, even with the designations of this policy, it is necessary to consolidate strategies that investigate the complexity of the healthy aging phenomenon in nursing practice in various methodological designs. Presumably the construction of a concept of healthy aging goes beyond delimiting the absence or presence of injuries and restrictions on the elderly's functionality. The phenomenon in its complexity requires the development of skills to experience aging in the best possible way and mobilizes a proposal for health promotion with a focus on maintaining functional capacity ${ }^{(1)}$.
However, the representation of phenomena, especially complex ones, requires referential support in theories. It is assumed that the application of theories in the field of health promotion ${ }^{(5-6)} \mathrm{can}$ assist nurses in understanding the aging process as well as the framework of nursing theories to more adequately support the NP operationalization in this field of professional performance.

Resolution 358/2009(7) of the Federal Nursing Council defines nursing process (NP) as a methodological instrument that guides nursing care, based on the practical application of nursing theories, and being developed in the stages of data collection or history of nursing; nursing diagnosis; nursing care planning; implementation; nursing assessment ${ }^{(7)}$. Thus, nursing theories and theoretical models have contributed to the care process, leading to the observation of nursing phenomena, interventions and outcomes ${ }^{(6)}$.

Nola Pender's Health Promotion Model (HPM) emerged in the 1980s in the United States, as a proposal to integrate nursing theories with behavioral sciences, based on the concept of health promotion ${ }^{(8)}$. This model has been used by nurses to understand healthy behaviors and to develop health promotion actions that bring significant benefits to people's quality of life. It seeks to base the concept of health promotion on actions that maintain or intensify individuals' well-being ${ }^{(8)}$. The model allows building a solid basis for the clinical practice of nurses, making it possible to plan, implement intervention and evaluate their actions ${ }^{(8)}$.

In 2010, a qualitative study, using the sociopoetic method, analyzed the construction of self-care actions by 11 elderly people at the Open University for Seniors (UnATI- Universidade Aberta para a Terceira Idade) at Universidade do Estado do Rio de Janeiro, relating to the conceptions of Nola Pender's theory ${ }^{(5)}$. The aforementioned study recognized the potential of this theoretical nursing framework to guide reasons that motivate or discourage people in engaging health-promoting behaviors, focusing especially on the perspective of self-care ${ }^{(5)}$. However, the conceptual elements, dynamics and mechanisms of the phenomenon have not been investigated in depth to produce a representative correlation with the theoretical or model structure of the phenomenon.

Returning to the question of the theory supporting NP, one can assume the importance of analyzes on the phenomenon of healthy aging and consequent conceptualization in the light of an interpretive theoretical framework. Thus, Nola Pender's MSP can serve as a descriptive and explanatory framework for the conditions that occur at the level of the healthy aging process. It can also allow an analysis of this process to serve as a basis for the elaboration of a model that addresses relevant dynamics for the practice of gerontological nursing. Such questions have originality in scientific studies related to the theme.

Given this context, it is necessary to provide nurses with a theoretical model that represents an instrument for understanding the phenomenon of healthy aging that is useful in gerontological nursing practice.

\section{OBJECTIVES}

To model the process of promoting healthy aging from the conceptual analysis proposed by Walker and Avant ${ }^{(9)}$ and Nola Pender's Health Promotion Model. 


\section{METHODS}

\section{Ethical aspects}

Considering the nature of theoretical research and the nonincorporation of human beings, submission to a Research Ethics Committee was waived.

\section{Theoretical-methodological framework}

This study used Nola Pender's HPM as a theoretical framework to model elements of the concept of healthy aging in gerontological practice. HPM has as its theoretical bases and sources the perspective of holistic nursing, social psychology and learning theory. It integrates some constructs, such as those of Social Cognitive Theory, which postulates the importance of cognitive processes in behavioral change ${ }^{(8)}$. It is based on three main points: the characteristics/personal experiences of individuals/ groups; knowledge and feelings about the behavior they want to achieve; desirable health promotion behavior ${ }^{(8)}$.

The methodological framework used was the conceptual analysis proposed by Walker and Avant ${ }^{(9)}$, which makes it possible to clarify the theoretical-practical relationship of the constructs applied in nursing.

\section{Type of study}

This is a descriptive and theoretical study, with a qualitative approach, which used conceptual analysis and modeling techniques to achieve its purpose.

\section{Methodological procedures}

To provide the elements for the modeling ${ }^{(10)}$ of a healthy aging promotion model, the conceptual analysis proposed by Walker and Avant was developed ${ }^{(9)}$. This analysis sought conceptions about healthy aging, to understand the challenges in relation to the promotion of healthy aging as advocated in the WHO world report on aging and health in $2015^{(1)}$. For this study, six of the eight proposed steps were followed ${ }^{(9)}$ : concept selection (concept of healthy aging), determination of the objectives for conceptual analysis (modeling the concept of healthy aging for nurses' clinical practice); identification of possible uses of the concept (how the concept of healthy aging is represented in the scientific literature); determination of the defining or critical attributes (extraction of words or expressions from studies, which represent the essence of the concept of healthy aging); identification of antecedents (factors that must occur before the concept of healthy aging addressed in the selected studies); consequence of the concept (events or incidents that occur as a result of the concept of healthy aging); definition of empirical indicators (which express ways in which the concept of healthy aging can be measured). The selection of the six analytical steps took place because they were considered more concerned with the concept's diagnostic properties.

As an evidence search technique for conceptual analysis, an integrative literature review ${ }^{(11)}$ was carried out from April to
May 2019 in the Cumulative Index to Nursing and Allied Health Literature (CINAHL), PubMed databases, which includes MEDLINE (Medical Literature and Retrieval System Online), SciVerse Scopus (Scopus) and Web of Science, using the descriptor "Healthy Aging". Complete articles published between January 2015 and March 2019, available in Portuguese, English or Spanish were included. Time frame (2015/2019) was defined to analyze the perspective of the concept of healthy aging from the world report on ageing and health. The exclusion criteria adopted were: articles that did not declare the concept of healthy aging used in the study. The research question used in the review was: what are the attributes, antecedents and consequences of the concept of healthy aging?

The integrative review stage was carried out by two members of the research team. From the titles, 1,793 articles were selected. After a text skimming of all abstracts, 208 articles were selected for reading in full. Then, 116 articles were read in full, since 92 articles were repeated among the databases searched. It is important to highlight that the majority of articles excluded in all databases was due to not declaring in the studies what was the concept of "healthy aging" adopted, i.e., they did not answer the guiding question. The final sample consisted of 36 articles analyzed (Figure1).

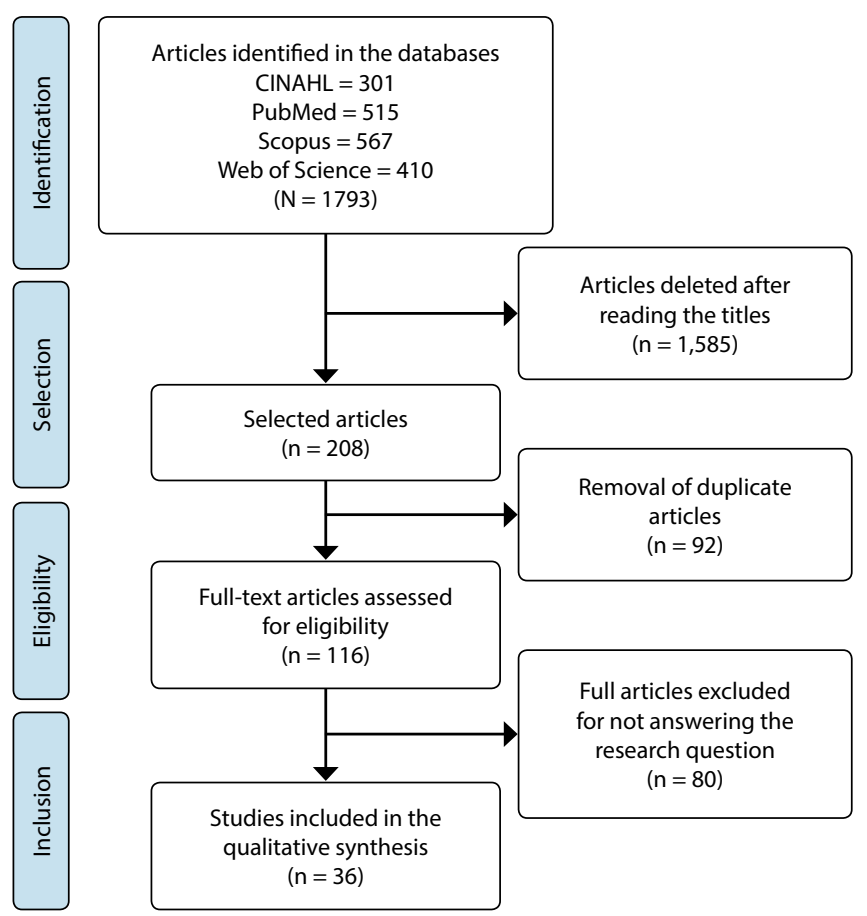

Figure 1 - Diagram of identification, selection and inclusion of studies, based on the Preferred Reporting Items for Systematic Review and MetaAnalysis (PRISMA)

After reading the material, expressions/words that the authors used to expand the concept of healthy aging addressed in the studies were extracted and listed. Then, the frequency with which each was mentioned in the studies was verified. According to the authors, attributes (words or expressions that represent the essence of the concept), antecedents (factors that must occur before the concept), and consequences (events that occur as a result of the concept) were established for healthy aging. 
For the modeling procedure ${ }^{(10)}$, Nola Pender's HPM was selected, which served as a reference for the construction of the Healthy Aging Promotion Model (HAPM). The properties of the elements of Nola Pender's HPM were semantically correlated with elements obtained from conceptual analysis that, through interpretation and abstraction, were organized in the model in the form of a diagram.

\section{RESULTS}

In conceptual analysis, seven antecedents, seven attributes and three consequences of the concept for healthy aging were identified, as presented in Chart 1.

The elements obtained from the conceptual analysis of healthy aging were arranged in a diagram representative of HAPM, using Nola Pender's HPM as a framework (Figure 2).

\section{DISCUSSION}

Nola Pender's HPM analyzes the behavior that leads to health promotion, through the relationship between three components: individual characteristics and experiences, feelings and knowledge about the behavior that one wants to achieve and the desirable health promotion behavior ${ }^{(8)}$.

This model aims to assist nurses in understanding factors that influence healthy behaviors from the biopsychosocial context ${ }^{(8)}$. When applying the concept of healthy aging in the HAPM diagram, it is understood to have produced a structure capable of guiding the operationalization of NP, enabling nurses to apply a theoretical model in nursing actions aimed at promoting healthy aging.

The construction of a model refers to the identification of parts that operate in a phenomenon, describing and explaining

Chart 1 - Elements of the concept of "Healthy Aging" identified in integrative review studies, Rio de Janeiro, Rio de Janeiro, Brazil, 2020

\begin{tabular}{|c|c|c|}
\hline \multicolumn{2}{|c|}{ Conceptual element } & \multirow{2}{*}{$\begin{array}{l}\text { Operational settings } \\
\text { Personal search to understand life-related issues, which may or may not lead to the development of } \\
\text { religious practices }{ }^{(12)} \text {. }\end{array}$} \\
\hline \multirow{7}{*}{$\begin{array}{l}\text { 号 } \\
\text { 岀 } \\
\text { 号 } \\
\text { 点 } \\
\text { z }\end{array}$} & Spiritual support & \\
\hline & Family support & Have a family network available to assist in overcoming crises that will inevitably occur throughout life ${ }^{(13-14)}$. \\
\hline & Self-care & Individuals' ability to take care of themselves ${ }^{(15)}$. \\
\hline & Well educated & $\begin{array}{l}\text { The fulfillment of a certain cycle of studies, which implies reading and writing so that individuals in the } \\
\text { aging process can effectively enter society }{ }^{(16)} \text {. }\end{array}$ \\
\hline & $\begin{array}{l}\text { Ability to perform activities of } \\
\text { daily living }\end{array}$ & $\begin{array}{l}\text { Ability to decide and perform the activities of daily living necessary for an independent and self-cared } \\
\text { life }^{(17)} \text {. }\end{array}$ \\
\hline & Healthy lifestyle & $\begin{array}{l}\text { Maintain a balanced diet, practice physical activity regularly, do not smoke and moderately consume } \\
\text { alcoholic beverages }{ }^{(18)} \text {. }\end{array}$ \\
\hline & Resilience & Coping ability, adaptation and positive responses to changes that occur with advancing age ${ }^{(19)}$. \\
\hline \multirow{7}{*}{ 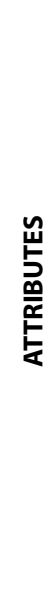 } & $\begin{array}{l}\text { Absence of cognitive } \\
\text { impairment }\end{array}$ & $\begin{array}{l}\text { Without memory impairment, it involves the entire sphere of mental functioning and implies the ability } \\
\text { to feel, think, perceive, remember, reason, form complex structures of thought and the ability to produce } \\
\text { responses to external requests and stimuli }{ }^{(20)} \text {. }\end{array}$ \\
\hline & $\begin{array}{l}\text { Absence of physical } \\
\text { impairment }\end{array}$ & $\begin{array}{l}\text { Absence of physical disability and disabilities that hinder physical performance and the performance of } \\
\text { instrumental and daily activities of life }{ }^{(21)} \text {. }\end{array}$ \\
\hline & Absence of disease & Absence of disease that compromises functional capacity ${ }^{(22)}$. \\
\hline & Absence of pain & Absence of chronic and severe pain in the hands, knees, hips or back ${ }^{(23)}$. \\
\hline & Psychological well-being & $\begin{array}{l}\text { Involves self-acceptance, managing life situations, autonomy, positive relationships, personal growth and } \\
\text { life purposes }{ }^{(24)} \text {. }\end{array}$ \\
\hline & Self-perceived health & $\begin{array}{l}\text { Good self-reported health status, which for the elderly should be linked to the physical, cognitive and } \\
\text { emotional context regarding aspects related to well-being and satisfaction with their own lives }{ }^{(25)} \text {. }\end{array}$ \\
\hline & Social engagement & $\begin{array}{l}\text { Have a relationship and family interaction available, which is able to assist in overcoming crises that will } \\
\text { inevitably occur throughout life }{ }^{(26-27)} \text {. }\end{array}$ \\
\hline \multirow{3}{*}{ 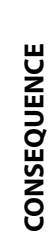 } & Autonomy & Individual ability to decision and command over actions, establishing and following the rules ${ }^{(28)}$. \\
\hline & Independence & Ability to live according to their own terms and participate in their own care ${ }^{(29)}$. \\
\hline & Quality of life & $\begin{array}{l}\text { "Individuals' perception of their insertion in life, in the context of the culture and value systems in which they live } \\
\text { and in relation to their goals, expectations, standards and concerns"(30). }\end{array}$ \\
\hline
\end{tabular}




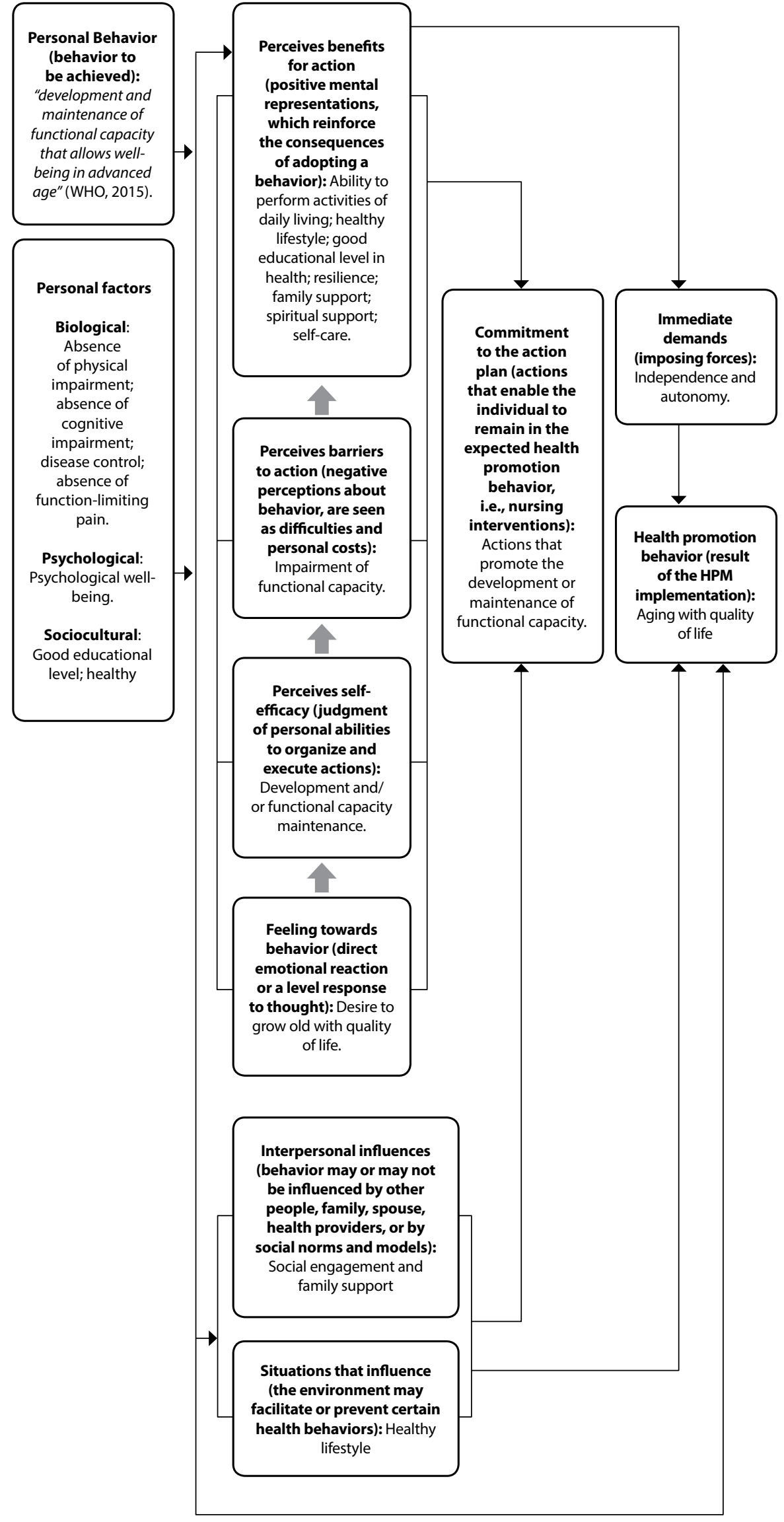

Figure 2 - Diagram of the Healthy Aging Promotion Model, Rio de Janeiro, Rio de Janeiro, Brazil, 2020 mechanisms or dynamics of process$\mathrm{es}^{(10)}$. Contrary to theories that tend to carry more abstract properties, the models are strongly supported at the empirical level. HAPM is a referenced model, and as such it needs to have an empirical anchor, however without being reductionist or purely mechanistic. It is understood that both the conceptual analysis and the theoretical framework ensured a modeling that preserved the mentioned characteristics.

To elaborate the diagram, the three main categories of Nola Pender's HPM were observed, namely ${ }^{(8)}$ : individual characteristics and experiences; feelings and knowledge about behavior; result of desirable health promotion behavior, put in a diagram.

The first major component of Nola Pender's HPM diagram, comprises "individual characteristics and experiences", previous behavior, which can interfere positively or negatively in health promotion behaviors ${ }^{(8)}$. Due to the concept of healthy aging adopted in the WHO world report on aging and health, in 2015, a health-promoting behavior that should be promoted is the development and/or maintenance of functional capacity ${ }^{(1)}$. This is a concept centered on individuals, on the course of life and perspectives based on intrinsic and functional capacity, not just absence of disease.

The WHO concept is based on biopsychosocial skills of individuals, and their interpellation with the environment and well-being ${ }^{(1)}$. This multidimensional construct is synonymous with a definition of good quality of life in the elderly, understood as individuals' perceptions about their position in life in the context of the culture and values in which they live, in relation to their goals $s^{(1,25)}$. Therefore, nurses should conduct actions aimed at health promotion that favor the maximization of functional capacity to provide the elderly with conditions for aging with quality of life, as recommended by the $\mathrm{WHO}^{(1)}$.

The "characteristics and personal experiences" category of Pender's HPM involves biopsychosocial factors, which are predictors of a given 
behavior $^{(8)}$. In this category, the following attributes were applied (absence of physical impairment, absence of cognitive impairment, absence of illness, psychological well-being, social engagement, and absence of pain limiting function) and background (good educational level, family support, spiritual support) of the concept of healthy aging identified in conceptual analysis.

Attributes represent the concept essence as well as the main idea that is transmitted by it and what characteristics are linked to them. Antecedents are events that happen a priori to the phenomenon (necessary for its occurrence), favoring the understanding of the context in which the concept is used ${ }^{(9)}$.

The attributes and antecedents of healthy aging identified in the conceptual analysis presented the determinants or factors that imply for an individual to conceive an aging with quality of life. Studies ${ }^{(3,31)}$ point out the importance of identifying and understanding the determinants and etiological factors of healthy aging, in a multidimensional view to support planning health promotion actions for the elderly population.

The presence of diseases, pain, physical and cognitive impairment can affect functional capacity, compromising healthy aging $^{(21)}$. Studies ${ }^{(3,32-33)}$ emphasize the importance of promoting, preventing and early identifying diseases and functional declines, in order to avoid or minimize damage to elderly's quality of life. Nurses can provide information regarding the adoption of healthy behaviors, such as healthy habits, participation in intellectual and voluntary activities, search for positive feelings, integration into the daily life of a therapeutic regime for the treatment of diseases and their sequel $\mathrm{I}^{(3-4,18)}$.

Psychological well-being involves self-acceptance, a positive relationship with others, autonomy, dominance over the environment, purpose in life and personal growth ${ }^{(24)}$. The implementation of strategies that favor mental health promotion has a potential to promote empowerment and adaptation to changes inherent to the aging process, strengthening psychological well-being ${ }^{(34)}$.

Social engagement, i.e., the composition of the social network and the practice of social activities that are able to assist in overcoming crises that will inevitably occur throughout life, are configured in social behaviors that influence elderly's health and well-being ${ }^{(26)}$. Nurses can encourage the elderly to maintain or develop social engagement behaviors, influencing their participation in social activities ${ }^{(26-27)}$.

The second major component of Pender's HPM, "specific behavior", refers to the "feelings and knowledge about the behavior" that one wants to achieve, being the central core of the diagram. These are modifiable aspects depending on the motivation that should start from nurses' assessment ${ }^{(8)}$. In the proposed diagram for promoting healthy aging, these aspects corresponded essentially to the antecedents (ability to perform activities of daily living, healthy lifestyle, good educational level in health, resilience, family support, spiritual support and selfcare) of the concept of healthy aging.

The background identified in the conceptual analysis stage for the concept of healthy aging, reinforces the need to adopt certain health behaviors for healthy aging with quality of life. Thus, these were applied to Pender's HPM, to facilitate nurses' understanding of the healthy aging phenomenon, in order to propose actions that optimize functional capacity. The maintenance and development of functional capacity is the essential element to achieve healthy aging described in the WHO global report on aging and health ${ }^{(1)}$.

Studies ${ }^{(4,18)}$ have shown that health professionals' advice on health behaviors (care with food, physical activity and reduced consumption of alcoholic beverages and smoking) can make individuals active about their health process, in addition to valuing and stimulating autonomy, factors that contribute to healthy aging.

Studies ${ }^{(16,35)}$ also pointed out that lower educational levels, among other socioeconomic factors, contribute negatively to physical health, with repercussions on quality of life and on healthy aging. Nurses can significantly contribute to improving health literacy in the elderly through educational work in health and health promotion.

The family context is revealed as a differential factor for healthy aging, transmitting to the elderly security, love and esteem that reflect on their well-being ${ }^{(14)}$. The family conceives of individuals the environment for the construction of their identity, architecting their space, where they situate their life history and their personal and social constructions, being intrinsic to understanding the aging process and its results ${ }^{(13-14)}$.

Thus, it is necessary for nurses to identify human responses to dysfunctions and disposition for improved family processes ${ }^{(36)}$ to plan interventions that enable the strengthening of family relationships that will consequently reflect in healthy aging promotion.

Spirituality is part of individuals' behavior throughout the existential cycle, since it involves finding a meaning for life, having hope and being resilient ${ }^{(12)}$. Spirituality becomes indispensable for communion with this great metamorphosis that is aging, and the elderly face this new phase of life positively ${ }^{(12)}$. Nurses must strengthen spiritual behavior, providing care that addresses elderly's specificity and subjectivity ${ }^{(37)}$.

Resilience is considered a protective factor of spirituality ${ }^{(38)}$, it is associated with quality of life and the potential to overcome adversity, physical comorbidities and functional capacity itself. This may explain how individuals with chronic illnesses are able to maintain control over the disease and positive self-perceived health, as well as being linked to healthy aging ${ }^{(19,26)}$.

The concept of resilience presupposes the potential of human beings to produce health. It is presented as one of the possible ways for health professionals, especially nurses to promote healthy aging. Nurses can promote health actions that develop or strengthen subjects to face adverse health conditions and the aging process itself ${ }^{(19)}$.

Therefore, health promotion with a focus on self-care can contribute to individuals taking care of themselves, positively influencing the preservation of their autonomy, independence, health conditions, quality of life and healthy aging ${ }^{(29)}$.

In the third major component of Pender's HPM, "behavior result"(8), the consequence of the concept of healthy aging identified in conceptual analysis were applied. Consequences represent events or incidents that occur as a result of the concept ${ }^{(9)}$. The independence and autonomy consequence identified in conceptual analysis covered the "immediate demands" of Pender's HPM, which will enable the elderly to exercise control over behavior change actions. 
Autonomy and independence are events linked to the concept of healthy aging. Studies ${ }^{(28-29)}$ reinforce the importance of nursing care aimed at promoting elderly's independence and autonomy so that they are co-responsible for the determinants of their health-disease and health care process, i.e., learning to take care of themselves and make relevant decisions about their actions in the process of living.

The quality of life consequence was applied to the "health promotion behavior" component of Pender's HPM, which comprises the expected result when implemented nursing care, which would be aging with quality of life. The development and maintenance of the functional capacity indicated in the WHO World Report on Aging and Health ${ }^{(1)}$, in 2015, proposes a strategy for aging with quality of life, being applied to the "commitment to action plan" component of Pender's HPM, thus idealizing the diagram for promoting healthy aging.

Nurses should develop skills to deal with the diversity of situations presented by this population. The application of the concept of healthy aging to Pender's HPM may clarify the NP operationalization, in order to identify the specific health needs of this clientele, enabling the planning of appropriate actions for the population.

Thus, in the first stage of NP (data collection), nurses must observe the elements of component 1 (characteristics and individual experiences) of the HAPM diagram, listing people's needs (behaviors that must be achieved). In the second stage of NP, it will be possible to identify nursing diagnoses, punctuating health-promoting behaviors that need to be taken on by observing the elements of component 2 of the diagram. For the stages of planning and implementing NP, nurses must establish a set of desirable health-promoting components and implement in practice health-promoting behaviors agreed with the person, i.e., proposing nursing interventions to achieve the results. In the fifth stage of NP (assessment), nurses will perform a procedural assessment of health-promoting behaviors that are being taken over, and if necessary, readjust the action plan to achieve the desired result (healthy aging).

\section{Study limitations}

A limitation was to deal with similar terms guaranteeing analysis of the concept of healthy aging. In the articles used for analysis, many authors used the terms "active aging" and "successful aging", which required interpretation on a case-by-case basis to ensure inclusion in situations where their use was synonymous with "healthy aging". Thus, the authors were judicious in semantic appreciation of terms, in order to deal with the terminological variability and ensure that the appropriate attributes, antecedents and consequences necessary for modeling were extracted.

\section{Contributions to nursing}

The NP operationalization guided by a model can direct nurses in the implementation of actions that maximize the elderly's functional capacity for an aging with quality of life, as well as providing opportunities for nurses to rethink health promotion strategies aimed at the aging population, committing to the population to promote healthy aging, as recommended by the WHO.

\section{FINAL CONSIDERATIONS}

The proposed HAPM represents a structure that in an instrumental way can guide the NP application in gerontological clinical practice.

The elements resulting from conceptual analysis could be aligned with Nola Pender's HPM and, with that, produce a model that seeks to preserve attributes of healthy aging, as well as to coordinate the theoretical elements with the empirical ones, which converges with the necessary theory-practice approach.

HAPM allows the multidimensionality of the healthy aging phenomenon, and presents the biopsychosocial factors that can influence behaviors that promote healthy aging. The model can be useful as a representation of the dynamics of aging phenomena and, as a result, support nurses in identifying diagnoses, establishing outcomes and implementing interventions aimed at promoting the elderly's health.

\section{REFERENCES}

1. World Health Organization (WHO). World report on ageing and health. Genebra: 2015.

2. Alvarez AM, Sandri JVA. Population aging and the Nursing commitment. Rev Bras Enferm. 2018;71(suppl 2):722-3. https://doi. org/10.1590/0034-7167-201871Sup201

3. Valcarenghi RV, Lourenço LFL, Siewert JS, Alvarez AM. Nursing scientific production on health promotion, chronic condition, and aging. Rev Bras Enferm. 2015;68(4):618-25. https://doi.org/10.1590/0034-7167.2015680419i

4. Tavares RE, Camacho ACLF, Mota CP. Nursing actions to the elderly in the family health strategy: integrative review. Rev Enferm UFPE. 2017;11(Supl.2):1052-61. https://doi.org/10.5205/reuol.10263-91568-1-RV.1102sup201722

5. Silva ACS, Santos I. Promoção do autocuidado de idosos para o envelhecer saudável: aplicação da teoria de Nola Pender. Texto Contexto Enferm. 2010;19(4):745-53. https://doi.org/10.1590/S0104-07072010000400018

6. Brandão MAG, Barros ALBL, Caniçali PC, Bispo GS, Lopes ROP. Nursing theories in the conceptual expansion of good practices in nursing. Rev Bras Enferm. 2019;72(2):577-81. https://doi.org/10.1590/0034-7167-2018-0395

7. Conselho Federal de Enfermagem (COFEN). Resolução COFEN-358/2009, de 15 de outubro de 2009: dispõe sobre a Sistematização da Assistência de Enfermagem e a implementação do Processo de Enfermagem em ambientes públicos ou privados, em que ocorre o cuidado profissional de Enfermagem. Brasília (DF); 2009. 
8. Pender NJ, Murdaugh CL, Parsons MA. Health promotion in nursing practice. 4th ed. Englewood Cliffs: Prentice Hall; 2002.340 p.

9. Walker LO, Avant KC. Strategies for theory construction in nursing. 6th ed. Upper Saddle River, New J: Pearson/Prentice Hall; 2019.272 p.

10. Bender M. Models versus theories as a primary carrier of nursing knowledge: a philosophical argument. Nurs Philos. 2018;19(1):1-8. https:// doi.org/10.1111/nup.12198

11. Mendes KDS, Silveira RCCP, Galvão CM. Integrative literature review: a research method to incorporate evidence in health care and nursing. Texto Contexto Enferm. 2008;17(4):758-64. https://doi.org/10.1590/S0104-07072008000400018

12. Dias EN, Pais-Ribeiro JL. Espiritualidade e qualidade de vida de pessoas idosas: um estudo relacional. Psicol, Saúde Doenças. 2018;19(3):591604. https://doi.org/10.15309/18psd190310

13. Seibel BL, Falceto OG, Hollist CS, Springer P, Fernandes CLC, Koller SH. Rede de apoio social e funcionamento familiar: estudo longitudinal sobre famílias em vulnerabilidade social. Pensando Fam. [Internet]. 2017 [cited 2020 Apr 08];21(1):120-36. Available from: http://pepsic. bvsalud.org/scielo.php?script=sci_arttext\&pid=S1679-494X2017000100010\&lng=pt\&nrm=iso

14. Bôas SSV, Araújo CM, Prates RV, Novais MM, Pinto DS, Reis LA. Capacidade funcional e suporte familiar em idosos longevos residentes em domicílio. Saúde (Santa Maria). 2020;46(1). https://doi.org/10.5902/2236583434375

15. Orem DE. Nursing: concepts of practice. St. Louis: Mosby; $2001.542 \mathrm{p}$.

16. Gonçalves Lima M, Carvalho J, Vasconcelos EM, Borba AK, Zimmermann R, Costa E. A importância da avaliação do letramento funcional em saúde no idoso: revisão integrativa. Rev Enferm Atual [Internet]. 2019 [cited 2020 Apr 08];90(28). Available from: http:// revistaenfermagematual.com.br/index.php/revista/article/view/537

17. Araújo GKN, Souto RQ, Alves AP, Sousa RCR, Ceballos AGC, Santos RC, et al. Functional capability and associated factors in the elderly living in the community. Acta Paul Enferm. 2019;32(3):312-8. https://doi.org/10.1590/1982-0194201900043

18. Flores TR, Nunes BP, Assunção MCF, Bertoldi AD. Healthy habits: what kind of guidance the elderly population is receiving from health professionals? Rev Bras Epidemiol. 2016;19(1):167-80. https://doi.org/10.1590/1980-5497201600010015

19. Lima GS, Souza IMO, Storti LB, Silva MMJ, Kusumota L, Marques S. Resilience, quality of life and symptoms of depression among elderlies receiving outpatient care. Rev Latino-Am Enferm. 2019;27:e3212. https://doi.org/10.1590/1518-8345.3133.3212

20. Andrade FLJP, Lima JMR, Fidelis KNM, Jerez-Roig J, Lima KC. Cognitive impairment and associated factors among institutionalized elderly persons in Natal, Rio Grande do Norte, Brazil. Rev Bras Geriatr Gerontol. 2017;20(2):186-96. https://doi. org/10.1590/1981-22562017020.160151

21. Moraes FLR, Corrêa P, Coelho WS. Avaliação da autonomia funcional, capacidades físicas e qualidade de vida de idosos fisicamente ativos e sedentários. Braz J Exerc Physiol Prescript[Internet]. 2018 [cited 2020 Apr 27];12(74):297-0. Available from: http://www.rbpfex.com.br/index. $\mathrm{php/rbpfex/article/view/1398}$

22. Mota TA, Alves MB, Silva VA, Oliveira FA, Brito PMC, Silva RS. Factors associated with the functional capacity of elderly individuals with hypertension and/or diabetes mellitus. Esc Anna Nery. 2020;24(1):e20190089. https://doi.org/10.1590/2177-9465-ean-2019-0089

23. Ferretti F, Silva MR, Pegora F, Baldo J, Sá CA. Chronic pain in the elderly, associated factors and relation with the level and volume of physical activity. BrJP. 2019;2(1):3-7. https://doi.org/10.5935/2595-0118.20190002

24. Cachioni M, Delfino LL, Yassuda MS, Batistoni SST, Melo RC, Domingues MARC. Subjective and psychological well-being among elderly participants of a University of the Third Age. Rev Bras Geriatr Gerontol. 2017;20(3):340-51. https://doi. org/10.1590/1981-22562017020.160179

25. Confortin SC, Giehl MWC, Antes DL, Schneider IJC, d'Orsi E. Positive self-rated health in the elderly: a population-based study in the South of Brazil. Cad Saude Publica. 2015;31(5):1049-60. https://doi.org/10.1590/0102-311X00132014

26. Silva Jr EG, Eulálio MC, Souto RQ, Santos KL, Melo RLP, Lacerda AR. The capacity for resilience and social support in the urban elderly. Ciênc Saude Colet. 2019;24(1):7-16. https://doi.org/10.1590/1413-81232018241.32722016

27. Pinto JM, Neri AL. Trajectories of social participation in old age: a systematic literature review. Rev Bras Geriatr Gerontol. 2017;20(2):259-72. https://doi.org/10.1590/1981-22562017020.160077

28. Lange C, Heidemann ITSB, Castro DSP, Pinto AH, Peters CW, Durand MK. Promoting the autonomy of rural older adults in active aging. Rev Bras Enferm. 2018;71(5):2411-7. https://doi.org/10.1590/0034-7167-2017-0570

29. Silva AM, Castro LFA, Botelho ACF, Santos DR, Frutuoso JRC, Marques AP, et al. Equilíbrio, autonomia e independência funcional de idosos ativos e sedentários: estudo preliminar. Rev Kairós. 2015;18(19):129-42. https://doi.org/10.23925/2176-901X.2015v18iEspecial18p129-142

30. The WHOQOL Group. The World Health Organization quality of life assessment (WHOQOL): position paper from the World Health Organization. Soc Sci Med. 1995;41(10):1403-9. https://doi.org/10.1016/0277-9536(95)00112-K

31. Kralj C, Daskalopoulou C, Prince M, Prina M. A systematic review of the determinants of healthy ageing. Innov Aging. 2017;1(1):1315. https:// doi.org/10.1093/geroni/igx004.4817

32. Castro APR, Vidal ECF, Saraiva ARB, Arnaldo SM, Borges AMM, Almeida MI. Promoting health among the elderly: actions in primary health care. Rev Bras Geriatr Gerontol. 2018;21(2):155-63. https://doi.org/10.1590/1981-22562018021.170133

33. Cardoso TFP, Martins MMFPS, Monteiro MCD. Unidade de cuidados na comunidade e promoção da saúde do idoso: um programa de intervenção. Referênc. 2017;serIV(13):103-14. https://doi.org/10.12707/RIV16071 
34. Gato JM, Zenevicz LT, Madureira VSF, Silvia TG, Celich KLS, Souza SS, et al. Mental health and quality of life of elderly people. Av Enferm. 2018;36(3):302-10. https://doi.org/10.15446/av.enferm.v36n3.68498

35. Lima JP, Abreu DPG, Bandeira EO, Brum NA, Mello MCVA, Varela VS, et al. Health literacy and associated factors in the elderly. Cogitare Enferm. 2019;24:e63964. https://doi.org/10.5380/ce.v24i0.63964

36. Herdman STH, Kamitsuru S. NANDA International Nursing Diagnoses: Definitions and Classification 2018-2020. Eleventh Edition. Thieme; 2018. $488 \mathrm{p}$.

37. Veras SMCB, Menezes TMO, Guerrero-Castañeda RF, Soares MV, Anton NFR, Pereira GS. Nurse care for the hospitalized elderly's spiritual dimension. Rev Bras Enferm. 2019;72(Suppl 2):236-42. https://doi.org/10.1590/0034-7167-2018-0685

38. Margaça C, Rodrigues D. Espiritualidade e resiliência na adultez e velhice: uma revisão. Fractal Rev Psicol. 2019;31(2):150-7. https://doi. org/10.22409/1984-0292/v31i2/5690 